\title{
ON SOME PROBLEMS OF TRANSLATING SYNTACTICAL CONSTRUCTIONS IN PRIVATE LEGAL DOCUMENTS.
}

\author{
S. THAMARAI PANDIAN, Head of Representation CIS countries, \\ DIA PHARMA, India \\ B.I. RUBINSKA, PHD in Pedagogy, Associate Professor, \\ National university of life and environmental sciences of Ukraine \\ E- mail: Slavinabe@gmail.com \\ ORCID: 0000-0003-3839-7562
}

\begin{abstract}
The article analyzes some problems of translating syntactical constructions in private legal documents. The purpose of the article is to identify certain isomorphic and allomorphic features of English and Ukrainian syntax in framework of solving particular translation problems. The first isomorphic feature is the length of sentences in the analyzed types of documents. In the process of translation the latter should be analyzed syntactically. The length may be preserved or the sentence can be divided into two or more sentences for better understanding by the reader. Another isomorphic feature is the usage of the Passive voice constructions. The translator can either use them in translation or substitute some of them by the Active forms for reasons of reducing redundant passive structures.

In provisos there are a lot of set expressions and formulas in limiting sentences that should be translated without change in syntax relationship. The allomorphic feature in the sentences is the difference in sentence structure. In the process of translation word order can be changed and some transformations are necessary. The comparative analysis showed that syntactic constructions may have common and divergent features that must be taken into account in the process of translation.
\end{abstract}

Keywords: allomorphic feature, isomorphic feature, length, private legaldocuments, translating syntactical constructions

Introduction. The topicality of the article is the following: there are few articles focused on the problem of linguistic and legal adequacy in translation of syntactical constructions in private legal documents $[1,2,3,4,5,6$,$] .$

Recent research and publications. Kozachek O.V considers peculiarities of translation to be the element of translation's technique and enumerates some lexical and grammatical difficulties of translation of such texts [2]. Shumilo I. and Snytsa T. have mentioned such syntactic specifics of translation as the usage of the Passive voice and modal verb "shall' to express order, obligation [5]. Mishchenko A.L. and Glezer R. look at syntactic construction as one of differentiation criteria of professional texts for scientific and technical translation. In this article he quotes classification of the most typical mistakes proposed by Gyobferich. Among them are syntactic mistakes: on the level of the member of a sentence they are: the wrong usage of cases, the choice of the wrong part of the sentence, the choice of possessive case instead of an object with a preposition, the usage of non-homogeneous parts in enumeration, breaking of valency (combination on syntactic level, absence of correspondence between subject and predicate) as well as mistakes on the level of the members of the sentence: wrong usage of the Infinitive, concentration of conjunctions and constructions in one

(C) S. T. Pandian, B.I. Rubinska

«International journal of philology» | «Міжнародний філологічний часопис» Vol. 10, № 1, 2019 
sentence, incomplete sentences, wrong connections between separate parts of the sentence. Translation mistakes are marked as those related to the level of the text [3].All these researches do not mention peculiarities of translation of syntactic constructions in private legal documents, which proves topicality of such research.

The object of this research is syntactic features of legal texts and ways of their rendering.

The subject of this article is the translation of syntactical constructions in private legal documents represented by an agreement.

The purpose of the present research is to determine some problems of translatability by analyzing the existing state of translation practice of private legal documents syntactical constructions in English as well as Ukrainian. So we have set ourselves the task to describe the syntactical structures in these documents and some problems of their translation.

The main methods of research are the studying and critical analysis of literature, methods of deduction and synthesis, comparative analysis.

Results.In legal documents an isomorphic linguistic feature is that sentences are typically long and complex. This is true for English, Ukrainian and many other languages. We will describe that feature in the British, American and Ukrainian private legal documents.

Syntax refers to the structure of the sentences and sequences of words. While words are the basic building blocks of the language that carry meanings, translation never remains at the lexical level but goes beyond. Words in translation never exist in isolation and their true meanings cannot be fully appreciated unless they are construed with reference to the ways they are structured.

Generally speaking, sentences in legal texts are longer than in other text types, and they may serve various purposes. Nevertheless, a complicated syntactical structure can cause comprehension difficulty for the reader, including the translator. It sometimes also makes the rendering into the target language difficult. We can find long and complex-compound sentences in all types of legal documents, private legal documents as well. For example,

"In the event the contractor becoming bankrupt or making a composition or arrangement with his creditors or having a proposal in respect of his company for a voluntary arrangement for a composition of debts in respect of his company to the court for the appointment of an administrator, or having a winding up order made or (except for the purposes of amalgamation or reconstruction) a resolution for voluntary winding up passed or having a provisional liquidator, receiver or manager of his business or undertaking duly appointed, or being placed under judicial management, or having possession taken, by or on behalf of the holders of any debentures secured by a floating charge, of any property comprised in or subject to the floating charge, the employment of the Contractor under this Contract shall be forthwith automatically terminated, but the said employment may be reinstated and continued, if the Proprietor and the Contractor, his trustee in bankruptcy, liquidator, provisional liquidator, receiver or manager as the case may be shall so agree".

In this example, the main clause is: "In the event of..., the employment.., shall be terminated". All the other clauses and qualifications are to cover the conditions and sentences with improved clarity.

The same situation can be found in the Ukrainian sentence in an insurance contract.

«За умовами цього договору страхове зобов'язання розглядається як правовідносини, згідно з якими одна сторона (страховик) зобов'язується в разі настання передбачуваної 
договором страхування події (страхового випадку), примайновому страхуванні і страхуванні відповідальності відшкодувати страхувальникові або іншій особі, на користь якої укладено договір страхування, завдані збитки в межах обумовленої страхової суми, а в разі особистого страхування виплатити відповідну грошову(страхову) суму».

According to the existing rules a translator should be adhere to the following procedures, when translating such sentences: 1 . carefully analyze the original sentence structure and sentence essential meaning to understand the message correctly and 2. to express and convey the meaning in the target language. Thus good knowledge of syntactical structures of both the source language and the target language is a "must" for a qualified interpreter and translator. Sometimes it may be necessary to divide the long sentence in the source language and write two or more sentences in the target language.

Another syntactical isomorphic feature is the use of passive constructions. The usage of the Passive Voice allows the writer to avoid naming or referring to the person or thing that performs the action. e.g.: "The contract was breached". This sentence simply states the fact, it doesn't indicate the person, who breached the contract. Lawyers use these constructions very often and sometimes overuse them. In translation these structures are translated with the help of the Passive

Довіреність Місто Ексетер, Сполучене королівство 2009 року

Громадянка Сполученого Королівства ,посвідчення

водія номер що

проживає за адресою:

(надалі - Довіритель), згідно попередньої домовленості, цією Довіреністю
Voice too. However, in the Ukrainian language they are not as commonly used as they are in English. In this case adjustments may be necessary. It is not obligatory that the passive structure is carried over in the target language.

Provisos are a traditional feature of English legal drafting in both private legal documents and statutes. They operate as conditions of qualifications. They are usually introduced by linguistic formula like: provided that, and provided that, and provided further that, provided always that, provided nevertheless that. Such formulas are used to vary or modify a more general provision, qualifying its operation in more particular situations [6, c 86].

Other limiting clauses common in private legal documents include the structure "subject to". It is used to express the intent that one provision (the master provision) prevails over another (the subject provision). For example, if clause 6 in an agreement begins with "subject to clause 5", then any inconsistency between the two clauses is resolved in favor of the master clause, clause 5. This structural part of a sentence is often used in ordinary agreements and also in wills, settlements and other instruments creating interest in succession. It is also often used in Statutes.

English and Ukrainian have allomorphic features as their sentence structure is different; moreover, legal documents operate on set expressions and clichés. Let us compare a sentence in Power of Attorney and Довіреність.

\section{Power of Attorney City of Exeter, United Kingdom}

The citizen of the United Kingdom
, driver's license
address:
(herein after referred to as Grantor),
authorizes according to the previous
agreement with the Power of Attorney

C S. T. Pandian, B.I. Rubinska

«International journal of philology» | «Міжнародний філологічний часопис» Vol. 10, № 1, 2019 
уповноважує:

який проживає за

адресою

та/або

який проживає за

адресою

які можуть діяти разом та незалежно один від одного:

користуватися та розпоряджатися

належними мені частиною квартири № яка розташована в місті Києві

по вулиці

в будинку №

представляти мої інтереси в усіх справах, в яких я є стороною з будь-яким статусом, що впливають на мої права та інтереси, а також з усіх питань, що можуть виникнути у мене в майбутньому.

In this sentence word order was changed in order to fit the target language requirements, making the text easier to perceive. Grammar transformations are required: target language verb should be substituted for a source language adjective as verbs are more characteristic for the English language, and consequently transposition: sentence word order was changed by the translator, placing "that belong to me" in the end. Another grammar transformation is the change of number (plural into singular, as well as lexical transformation, where the word "ycix" is reconstructed as "any" in the English language.

Conclusions and discussion. In both languages sentences in private legal documents are

long, which is an isomorphic feature. This makes the translator analyze their syntactic structure and where necessary divide them into two or more sentences. Lawyers also use a lot of Passive Voice constructions, which is another isomorphic feature in both contrasted languages. Therefore, they should be translated with the help of these constructions. But one should remember that they are less often here under

address: resident at the , and/or resident at the

address: and/or resident at the address,

acting collectively or separately

one from another

to use and to dispose of the part

of the flat №

situated in Kyiv City in the building №

on Street and the part of the

flat № situated in Kyiv City in the building №_on Street, that belong to me; to represent my interests at any hearing to which I may be a party with any status which may affect my rights and interests, as well as at any other issue that might arise in the future.

used in the Ukrainian language. There are also allomorphic features that present difficulty for a translator. Private legal documents are full of set expressions and clichés in limiting clauses. Grammar transformations are required in this case. Further research of the problem of syntactic structures translation in private legal documents is necessary.

\section{Список використаних джерел}

1. Желясков В. Я. Труднощі й особливості перекладу текстів, що належать до галузі права.Науковий вісник Міжнародного гуманітарного університету. Сер: Філологія, Вип 18. Т 2. Ізмаїл, 2015. C. $16-22$.

2. Козачек О. В. Особливості перекладу юридичних текстів. URL: http://nbuv.gov.ua/UJRN/nvxdupmk_2 016_2_6 7www.irbisnbuv.gov.ua/cgi.../cgiirbis_64.exe?. (дата звернення 10.10.18.)

3. Міщенко А. Л. Лінгвістика фрахових мов та сучасна модель науковотехнічного перекладу. URL: https://books.google.com/books/abou t/Лінгвістика_фахових_м.html?id...(дата звернення: 12.09 .18$. 
4. Чепурна О. В. Особливості методичної роботи над англомовними юридичними текстами у процесі перекладу URL: Вісник Дніпропетровського університету імені Альфреда Нобеля. Сер.: Філологічні науки, Вип. 2. Дніпропетровськ,2013. - С. 321-325.

URL: http://nbuv.gov.ua/UJRN/vduepf_2013_2_4 6 7. (дата звернення: 15.10.18.)

5. Шумило .І. Особливості перекладу юридичних текстів. Філоло-гічний дискурс, Вип. 4, 2016. С. 266272.URL: http://nbuv.gov.ua/UJRN/fild_20 16_4_30 (дата звернення 10.10.18.)

6. Aitken J.R. and Butter P. The Elements of Drafting .Sydney. LawbookCo, 2004, P 86.

\section{References}

1. Zheliaskov, V. Ya. (2015). Trudnoshchi y osoblyvosti perekladu tekstiv, shcho nalezhat do haluzi prava.[Difficulties and Peculiarities of texts that belong to the law sphere], Naukovyi visnyk Mizhnarodnoho humanitarnoho universytetu. Ser.: Filolohiia, Vypusk 18,[issue18], Vol.2. Izmail,16 - 22.

2. Kozachek, O.V. (2016). Osoblyvosti perekladu yurydychnykh tekstiv. [Legal Texts Translation Peculiarities]URL:
http://nbuv.gov.ua/UJRN/nvxdupmk_2016_ 2_6 7www.irbis-

3. Mishchenko, A. L. (2013). Linhvistyka fakhovykh mov ta suchasna model naukovo-tekhnichnoho perekladu.[Linguistics of Specialized Languages and Modern Model of Science and Technical Translation]. - Available at: https://books.google.com/books/about/Лінг вістика_фахових_м.html?id...

4. Chepurna, O. V. (2013). Osoblyvosti metodychnoi roboty nad anhlomovnymy yurydychnymy tekstamy u protsesi perekladu [Peculiarities of methodology Work on English Legal Texts] Available at: http://nbuv.gov.ua/UJRN/vduepf_2013_2_4 67.

5. Shumylo, I. (2016). Osoblyvosti perekladu yurydychnykh tekstiv [Peculiarities of Legal Texts Translation]. Available http://nbuv.gov.ua/UJRN/fild_4_30

6. Aitken, J.R., and Butter, P. (2004), The Elements of Drafting, $10^{\text {th }}$ edition, / J.R. Aitken, , P. Butter. Sydney: LawbookCo, 86.

\section{ПРО ДЕЯКІ ПРОБЛЕМИ ПЕРЕКЛАДУ СИНТАКСИЧНИХ КОНСТРУКЦІЙ У ПРИВАТНИХ ЮРИДИЧНИХ ДОКУМЕНТАХ}

\section{С. Т. Пандіан, Б. І. Рубінська}

Анотація. В статmі аналізуються деякі проблеми перекладу синтаксичних конструкцій у приватних юридичних документах. Метою статті $\epsilon$ аналіз певних ізоморфнних та аломорфних рис англійського $і$ українського синтаксису в аспекті вирішення перекладацьких завдань. Перша ізоморфна риса це - довжина речень у аналізованих типах документів, яка може як зберігатися в процесі перекладу, так $i$ підлягати трансформації за допомогою розділення на два або більше речень для їх кращого розуміння читаючим. Іншою ізоморфною рисою $є$ використання конструкцій Пасивного Стану. Перекладач може їх використати при перекладі, але якщо їх занадто багато в англійській мові, він може замінити деякі з них у перекладі. У провізо є багато сталих виразів та формулювань у обмежувальних реченнях, які слід перекладати без заміни синтаксичних відносин. Аломорфнню рисою українського $i$ англійського синтаксису є відмінності у структурі речень. В процесі перекладу порядок слів можна змінювати, для чого залучаються відповідні трансформації. Контрастивний аналіз показав, що синтаксичні конструкції можуть мати як спільні так і різні риси, які слід враховувати в процесі перекладу.

Ключові слова: аломорфна риса, ізоморфнна риса, довжина, приватні юридичні документи, перекладаючи синтаксичні конструкції

C S. T. Pandian, B.I. Rubinska

«International journal of philology» | «Міжнародний філологічний часопис» Vol. 10, № 1, 2019 